\title{
Determination the Natural Radioactivity Levels at Selected Regions in Al-Najaf Governorate
}

\author{
Nada M. Hasan ${ }^{1, *}$, Jamal K. Alsaedi², Salam K. Alnasri³ ${ }^{3}$, Ali A. Abdulhasan² \\ ${ }^{1}$ Radioactive Waste Management and Treatment, Ministry of Science and Technology, Baghdad, Iraq \\ ${ }^{2}$ Nuclear Research and Applications, Ministry of Science and Technology, Baghdad, Iraq \\ ${ }^{3}$ Radiation and Nuclear Safety, Ministry of Science and Technology, Baghdad, Iraq
}

\begin{tabular}{ll}
\hline \multicolumn{1}{c}{ Article's Information } & \multicolumn{1}{c}{ Abstract } \\
\hline Received: & The natural radioactivity levels for radium (226Ra), thorium (232Th) and \\
$04-10-2020$ & potassium $(40 \mathrm{~K})$ have been determined in soil samples selected from different \\
Accepted: & regions in Najaf governorate in Iraq. The samples were collected from the \\
13-06-2021 & ground surface. Eight samples were measured by gamma ray spectroscopy using \\
Published: & high purity germanium detector. The levels of radionuclides concentrations in \\
$27-06-2021$ & selected samples ${ }^{232} \mathrm{Th}, 226 \mathrm{Ra}$ and ${ }^{40 \mathrm{~K}}$ were in the range of $(2.5 \pm 0.29$ to $7.7 \pm 0.52)$ \\
Keywords: & Bq/kg $(6.3 \pm 0.43$ to $16.4 \pm 1.9)$ Bq/kg and (31.5 \pm 3.4 to 204.1 \pm 11.9$)$ Bq/kg for, \\
Natural Radioactivity & respectively. The mean Radium Equivalent Activity, External and Internal \\
Gamma ray & Hazard Indices, the Absorbed Dose Rate in Air and the Annual Effective Doses \\
High purity germanium detector & Equivalent were studied and found these parameter are less than the reported \\
Radiological hazard & values. Therefore, the radioactivity in the studied area in Najaf does not pose \\
Soil & any radiological hazard to the general public. \\
\hline
\end{tabular}

DOI: $10.22401 /$ ANJS.24.2.06

*Corresponding author: nada66_altai@yahoo.com

\section{Introduction}

There are big interests to study the natural radioactivity in soil due to exposure radiation for humans. The radioactive levels have different effects on human health. The international regulations recommended a continuance survey and monitoring of the environment's samples in order to ensure that potential changes in the radiation environment activity due the nuclear plants and industrial activities are in control [1].

The humans are exposed on radiation from sources including: cosmic rays, natural radionuclide's in water, air, soil and plants, in addition the artificial radioactivity was found in the fallout from nuclear tests and medical application [2]. The International Atomic Energy Agency (IAEA) estimated that $80 \%$ of the contribution doses derived from natural radionuclides in the environment while the remaining $20 \%$ is from cosmic rays and nuclear operations [3]. The geography, geology and the climate causes a different level of radioactivity in the environment and the external exposure associated with radiological effects [4]. Natural radionuclides in the earth's environment consists mainly of potassium ${ }^{238} \mathrm{U},{ }^{226} \mathrm{Th}$ and ${ }^{40} \mathrm{~K}$ in addition the radioactive gas radon [5]. Therefore, the natural radioactivity measurements in soil's samples are a great benefit for many research groups throughout the world. This is led to worldwide national survey in the last two decades. These studies provide important role in the radiation protection and a preservation of human health. Wide interests by researchers were made through past and until now [6-10]. In spite of several studies and measurements have been conducted in several Iraqi governorates, there are few areas not studied for different reasons.

The objective of this present work is to determine the specific activity concentrations of ${ }^{226} \mathrm{Ra},{ }^{232} \mathrm{Th}$ and ${ }^{40} \mathrm{~K}$ in surface soil samples in some selected region in Nineveh province in Iraq using HPGe detector. The results can serve as a database in the monitoring of any radioactivity variation in the environment. It is very important to assess the health impact of radionuclides to the human population, by calculation the radiological effects.

\section{Experimental Work \\ 2.1 Geology of area}

This study was conducted in Najaf governorate $170 \mathrm{~km}$ south-west from city of Baghdad (capital city of Iraq). The coordinates of area is $32^{\circ} 01^{\prime} 44^{\prime \prime} \mathrm{N} 44^{\circ} 20^{\prime} 23^{\prime \prime} \mathrm{E} 30^{\circ} 3$ " $29^{\prime \prime}$ $\mathrm{N}, 31^{\circ} 13,44^{\prime \prime} \mathrm{E}$. The area of Najaf governorate is one of the important areas in terms of hydrogeological view due to containing the groundwater reservoirs [11].

\subsection{Soil sampling}

Eight soil samples were collected from different sites of Najaf governorate at ground surface. Initially, the samples were crushed via an agate electric mill, and each sample was dried by oven at constant temperature of $200^{\circ} \mathrm{C} \pm 5^{\circ} \mathrm{C}$ 


\section{Al-Nahrain Journal of Science}

ANJS, Vol.24 (2), June, 2021, pp. 33-40

for two hours to remove humidity and maintain a constant weight during measurement. Then grinded the samples with the particle size of approximately $200 \mu \mathrm{m}$. Finally, putted the dried samples in standard containers of Marinelli Baker with a net fixed at $500 \mathrm{~g}$ and stored for one month to allow for irradiative balance between ${ }^{226} \mathrm{Ra}$ and ${ }^{222} \mathrm{Rn}$ daughter. [12].

\subsection{Measurement of natural radioactivity}

Genie 2000 gamma spectroscopy system was employed for this purpose (Canberra Industries, USA) for the analysis of samples. The system utilized the (HpGe) detector with the dimension of (Canberra Industries, USA) with an energy resolution of $2.2 \mathrm{keV}$ and a relative efficiency is $50 \%$ at the ${ }^{60} \mathrm{Co} 1.332 \mathrm{MeV}$ gamma line. The detector has been shielded with bricks of lead to reduce background radiation levels. The system was controlled via a personal computer through the Ethernet and the data were collected and saved for further analyzing via the Geany-2000 software (Canberra Industries, USA). The system was calibrated for the energy using point sources $\left({ }^{137} \mathrm{Cs},{ }^{60} \mathrm{Co}\right)$ with energies $(661,1172$ and 1332$) \mathrm{keV}$ respectively and the relative efficiency calibration using standard Marinelli beaker calibration that saved in device library, the source is containing ${ }^{241} \mathrm{Am},{ }^{109} \mathrm{Cd},{ }^{57} \mathrm{Co},{ }^{139} \mathrm{Ce}$, ${ }^{60} \mathrm{Co},{ }^{85} \mathrm{Sr},{ }^{88} \mathrm{Y},{ }^{137} \mathrm{Cs}$, and ${ }^{203} \mathrm{Hg}$. The measurements was accuracy tested by analyses of standard sources MG651095 used mixed radionuclide source $\left({ }^{203} \mathrm{Hg},{ }^{241} \mathrm{Am}\right.$, ${ }^{109} \mathrm{Cd},{ }^{139} \mathrm{Ce},{ }^{88} \mathrm{Y},{ }^{137} \mathrm{Cs},{ }^{57} \mathrm{Co},{ }^{113} \mathrm{Sn},{ }^{85} \mathrm{Sr}$, and $\left.{ }^{60} \mathrm{Co}\right)$ of density $0.985 \pm 0.01 \mathrm{~g} \mathrm{~cm}^{-3}$, volume $500 \pm 5.0 \mathrm{~cm}^{3}$, mass $492.5 \mathrm{~g}$, reference date $25-8-2011$ and the total activity 1.1 $\mu \mathrm{Ci}$. The counting time was $7200 \mathrm{~s}$ for each sample. I was comparison of results between experimental data and the results published in certificate data as shown in Table 1.

Table 1. The comparison of results between experimental data and the results published in certificate data.

\begin{tabular}{|c|c|c|c|c|c|c|c|c|c|}
\hline $\begin{array}{l}\text { Radio- } \\
\text { Nuclide }\end{array}$ & $\begin{array}{c}\text { Half life } \\
\text { days }\end{array}$ & $\begin{array}{c}\text { Activity } \\
\text { certificate } \\
-\mathbf{k B q} \\
\end{array}$ & $\begin{array}{c}\text { Activity } \\
\text { experime- } \\
\text { tntal- kBq }\end{array}$ & $\underset{\%}{\text { Accuracy }}$ & $\begin{array}{l}\text { Radio- } \\
\text { nuclide }\end{array}$ & $\begin{array}{c}\text { Half } \\
\text { life } \\
\text { days } \\
\end{array}$ & $\begin{array}{c}\text { Activity } \\
\text { certificate } \\
\text {-kBq } \\
\end{array}$ & $\begin{array}{c}\text { Activity } \\
\text { experime- } \\
\text { ntal- kBq }\end{array}$ & $\underset{\%}{\text { Accuracy }}$ \\
\hline Am-241 & 157800 & 5.883 & 5.321 & 9.55 & Sn-113 & 115.1 & 2.905 & - & - \\
\hline Cd-109 & 462.6 & 12.80 & - & - & Sr-85 & 64.78 & 3.855 & - & - \\
\hline $\mathrm{Ce}-139$ & 137.5 & 0.499 & - & - & Y-88 & 106.6 & 5.072 & - & - \\
\hline Co-60 & 1925.4 & 3.217 & 2.93 & 8.92 & $\mathrm{Hg}-203$ & 46.72 & 2.006 & - & - \\
\hline Cs-137 & 11019 & 3.106 & 2.92 & 5.99 & Co-57 & 271.26 & 0.447 & - & - \\
\hline
\end{tabular}

The concentration of radioactivity of ${ }^{238} \mathrm{U}$ was determined by using the energies $(186.2 \mathrm{keV}, 351.9 \mathrm{keV}$ and $609.2 \mathrm{keV})$ to the isotopes $\left({ }^{226} \mathrm{Ra},{ }^{214} \mathrm{~Pb}\right.$ and $\left.{ }^{214} \mathrm{Bi}\right)$ respectively, the radioactivity of ${ }^{232} \mathrm{Th}$ was determined by using the energies (583.1 keV and $911.1 \mathrm{keV})$ from the isotopes $\left({ }^{208} \mathrm{Tl}\right.$ and $\left.{ }^{228} \mathrm{Ac}\right) \mathrm{keV}$ respectively. The radioactivity of ${ }^{40} \mathrm{~K}$ was determined using a single peak of $1460 \mathrm{keV}$ as shown in Figure 1.

Using equation (1) to computed the concentration of radioactivity in the measured samples [13]:

$$
A\left(\frac{B q}{k g}\right)=\frac{C P S}{\text { eff.I } . M}
$$

where $A$ is the radioactivity concentration given at $B q / k g$, $C P S$ is the net count rate under the peak per second, eff is the detector efficiency at the specific $\gamma$-ray energy, $\mathrm{I} \gamma$ is the absolute transition probability of the specific $\gamma$-ray and $M$ is the mass of the sample in $(\mathrm{kg})$.

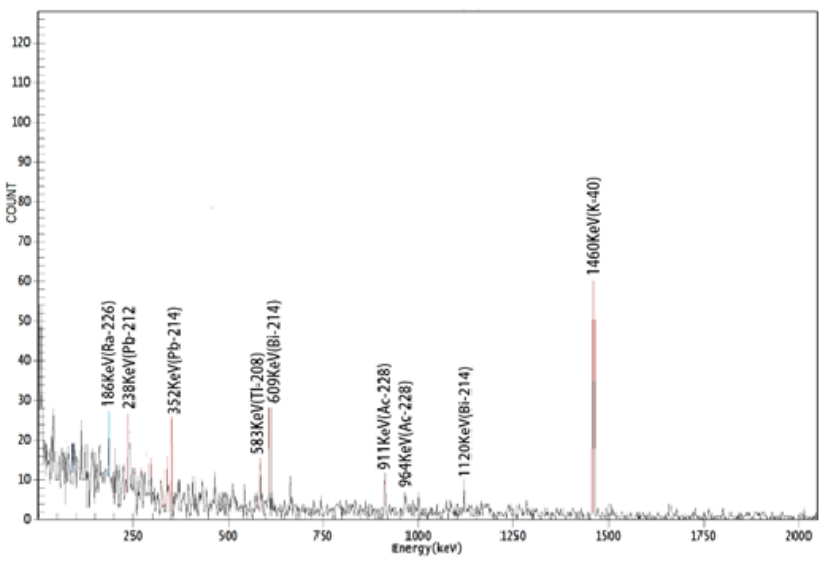

Figure 1. The gamma ray spectrum of Al-Rohaneya using HpGe detector.

\subsection{Calculation the radiological effects \\ 2.4.1 Radium equivalent activity ( $R a e q)$}

The distribution of natural radionuclides in samples is not uniform. This index used to obtain the sum of the activities ${ }^{226} \mathrm{Ra},{ }^{232} \mathrm{Th}$ and ${ }^{40} \mathrm{~K}$ where the radiation hazards associated with the radionuclide's is estimated by calculating the activity of the radium equivalent $\left(R a_{e q}\right)$.It is based on the assumption that $10 \mathrm{~Bq} / \mathrm{kg}, 7 \mathrm{~Bq} / \mathrm{kg}, 130 \mathrm{~Bq} / \mathrm{kg}$ for each of ${ }^{226} \mathrm{Ra},{ }^{232} \mathrm{Th}$, and ${ }^{40} \mathrm{~K}$ respectively. This calculation is 


\title{
Al-Nahrain Journal of Science
}

\author{
ANJS, Vol.24 (2), June, 2021, pp. 33-40
}

produces the same dose as gamma radiation, which is obtained by [14]:

$$
R a_{e q}(B q / k g)=A_{R a}+1.43 A_{T h}+0.077 A_{K}
$$

where $A_{R a}, A_{T h}$ and $A_{K}$ are specific activity of the radionuclides ${ }^{226} \mathrm{Ra},{ }^{232} \mathrm{Th}$ and ${ }^{40} \mathrm{~K}$ respectively. The permissible limit of $R a_{e q}$ is $370 \mathrm{~Bq} / \mathrm{Kg}$ in soil sample that contain ${ }^{238} \mathrm{U},{ }^{232} \mathrm{Th}$ and ${ }^{40} \mathrm{~K}$ measured in $\mathrm{Bq} / \mathrm{Kg}$ [14].

\subsubsection{Radiation hazard indices}

The external and internal hazard index is criterion for assessing the radiological suitability of materials. The external hazard index $\left(H_{e x}\right)$ was calculated by the following [15]:

$$
H_{e x}=\frac{A R a}{370}+\frac{A T h}{259}+\frac{A K}{4810} \leq 1
$$

The internal hazard index $\left(H_{\text {in }}\right)$ can be calculated by [16]:

$$
H_{\text {in }}=\frac{A R a}{185}+\frac{A T h}{259}+\frac{A K}{4810} \leq 1
$$

The value of this indicator should be less than unit the radiation hazard to be negligible. $H_{e x}$ equal to unity corresponds to the upper limit of $R a_{e q}(370 \mathrm{~Bq} / \mathrm{kg})$.

\subsubsection{The Absorbed dose rate in air $(D)$}

The absorbed dose rate in air in one meter above the ground surface and this is an express the received dose the open air. This factor is an important quantity to evaluate when considering radiation risk [17]. This factor can be calculated using the fallowing [18].

$$
D(n G y / h)=0.462 A_{R a}+0.604 A_{T h}+0.042 A_{k}
$$

where $0.43,0.67$ and $0.042 n G y \cdot h^{-1} / B q . \mathrm{kg}^{-1}$ are the conversion factors of ${ }^{226} \mathrm{Ra},{ }^{232} \mathrm{Th}$ and ${ }^{40} \mathrm{~K}$, respectively.

\subsubsection{Activity utilization index (AUI)}

An activity utilization index $(A U I)$ were applied to calculation of dose rates in air from different combinations of the three radionuclides in soils. This factor can be calculated using the fallowing [18]:

$$
A U I=\left(\frac{A_{R a}}{50 B q / K g}\right) f_{R a}+\left(\frac{A_{T l}}{\frac{50 B q}{K g}}\right) f_{T h}+\left(\frac{A_{K}}{500 B q / K g}\right) f_{K}
$$

where $f_{\mathrm{Ra}}, f_{\mathrm{Th}}$ and $f_{\mathrm{K}}$ are the fractional contribution to the total dose rate in air due the gamma radiation from the actual radioactivity.

\subsubsection{Representative level index (I)}

This factor is the representative level index of gamma radioactivity that can be calculated by: [19].

$$
I=\frac{A_{R a}}{150}+\frac{A_{T h}}{100}+\frac{A_{K}}{1500} \leq 1
$$

Radioactive Heat Production Rate (RHP): The decay of radioactive isotopes are producing energy and part of this energy are converted to heat, the result heat from the radioactive isotopes decay are ignored except the contribution of ${ }^{238} \mathrm{U},{ }^{232} \mathrm{Th}$ series and ${ }^{40} \mathrm{~K}$, this unit can be calculated by [20]:

$$
\begin{aligned}
R H P= & 10^{-5} \rho\left(9.52 A_{u}+2.56 A_{T h}+\right. \\
& \left.3.48 A_{K}\right) \mu W m^{-3}
\end{aligned}
$$

where $\rho$ is the sample density (in $\mathrm{kg} / \mathrm{m}^{3}$ ), the unit of activity concentration to ${ }^{238} \mathrm{U},{ }^{232} \mathrm{Th}$ is $\mathrm{ppm}$, the unit of activity concentration to ${ }^{40} \mathrm{~K}$ is $\%$. It can be converted the activity concentration unit from $\mathrm{Bq} / \mathrm{kg}$ to $\mathrm{ppm}$ or $\%$ using conversion factors [21].

\subsubsection{Annual effective doses equivalent ( $A E D E)$}

Using factor of $0.7 \mathrm{SvGy}^{-1}$ to calculate the annual effective dose received estimated average equivalent, which was used to convert the absorbed dose rate to human effective dose equivalent of $20 \%$ with an outdoor and $80 \%$ for indoor. The annual effective doses equivalent outdoor and indoor is calculated using Equation (9) and (10) [22].

$$
\begin{gathered}
A E D E_{\text {outdoor }}\left(\frac{\mu S v}{y}\right)=D\left(n G y h^{-1}\right) \times 8760 h \times \\
0.2 \times 0.7 S v G y^{-1} \times 10^{-6}
\end{gathered} \begin{gathered}
\ldots(9) \\
A E D E_{\text {Indoor }}\left(\frac{\mu S v}{y}\right)=D\left(n G y h^{-1}\right) \times 8760 h \times 0.8 \times \\
0.7 S v G y^{-1} \times 10^{-6}
\end{gathered}
$$

\subsubsection{Excess lifetime cancer risk ( $E L C R)$}

The probability of cancer is occurring even in few doses and this probability increases with increasing the doses and become clear when the doses become more than $100 \mathrm{mSv}$. using equation (11) to calculated this index [23]:

$$
E L C R=A E D E \times L T \times R F
$$

where $L T$ is a lifetime (70 years), $R L$ is a risk factor. The risk factor represents the risk of fatal cancer per Sievert $\left(0.05 \mathrm{~S} \mathrm{v}^{-1}\right)$.

\subsubsection{Annual gonadal dose equivalent ( $A G D E$ )}

Radiation effect varies is depending on the quality of living cells. Therefore the organs UNSCEAR focus to the gonads, the active bone marrow, and bone surface cells. Were calculated this factor using [24]:

$$
A G D E\left(\frac{\mu S v}{\text { year }}\right)=3.09 A_{R a}+4.18 A_{T h}+0.31 A_{K}
$$

\section{Results and Discussion}

\subsection{The activity concentration}

The concentrations of the radioactivity measurement of ${ }^{232} \mathrm{Th},{ }^{226} \mathrm{Ra}$, and ${ }^{40} \mathrm{~K}$ in soil samples selected from 8 sites in Al-Najaf are conducted using gamma ray spectrometer. The range of the samples activity concentration values are $(2.5 \pm 0.29$ to $7.7 \pm 0.52) \mathrm{Bq} / \mathrm{kg},(6.3 \pm 0.43$ to $16.4 \pm 1.9)$ $\mathrm{Bq} / \mathrm{kg}$ and (31.5 \pm 3.4 to $204.1 \pm 11.9) \mathrm{Bq} / \mathrm{kg}$ for ${ }^{232} \mathrm{Th},{ }^{226} \mathrm{Ra}$ and ${ }^{40} \mathrm{~K}$, respectively. The average activity values for the ${ }^{232} \mathrm{Th},{ }^{226} \mathrm{Ra}$, and ${ }^{40} \mathrm{~K}$ are $(4.9,12.06$ and 76.06$) \mathrm{Bq} / \mathrm{kg}$ respectively. These values of radioactivity concentration obtained in this study are below the international average value of $35 \mathrm{~Bq} / \mathrm{kg}$ for ${ }^{232} \mathrm{Th} 30 \mathrm{~Bq} / \mathrm{kg}$ for ${ }^{226} \mathrm{Ra}$ and 400 $\mathrm{Bq} / \mathrm{kg}$ for ${ }^{40} \mathrm{~K}[16]$ as shown in Table 2. 


\section{Al-Nahrain Journal of Science}

ANJS, Vol.24 (2), June, 2021, pp. 33-40

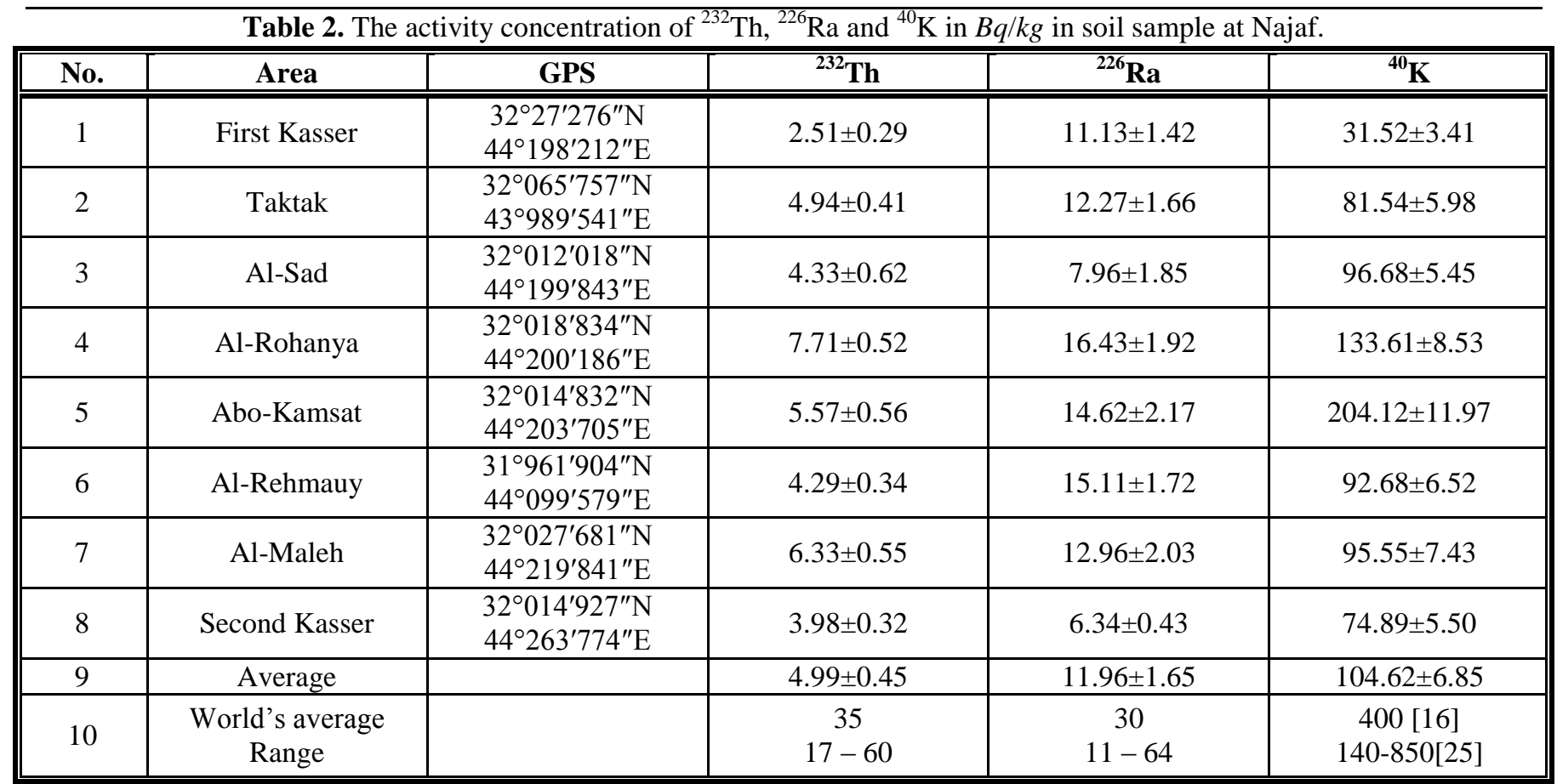

\subsection{Radiological effects}

Calculated assessment of radiation hazards in this work are shown in Table 3 . The present work of radium equivalent activity $\left(R a_{e q}\right)$ owing the activity concentration of $\left({ }^{232} \mathrm{Th}\right.$, ${ }^{226} \mathrm{Ra}$ and ${ }^{40} \mathrm{~K}$ ) natural radionuclides from all location varies is (17.1-37.89) $\mathrm{Bq} / \mathrm{kg}$. The mean value of $R a_{e q}$ is 26.235 Bq/kg is much less than the threshold value of 370 $\mathrm{Bq} / \mathrm{kg}$, The range of Radiation Hazard Indices are presented is found to be $(0.03-0.1),(0.07-0.15)$ for external and internal hazard, the value of this indicator was less than unit so the radiation hazard was neglected. Mean value of air absorbed gamma radiation dose rate $(D)$, Activity Utilization Index $(A U I)$, Radioactive heat production $(R H P)$ rate, annual effective dose equivalent $(A E D E)_{\text {out }}$, annual effective dose equivalent $(A E D E)_{i n}$, are
(11.02 nGy/h, 0.17, $1.35\left(\mu \mathrm{W} / \mathrm{m}^{3}, 0.015 \mu \mathrm{Sv} / \mathrm{y}, 0.061\right.$ $\mu \mathrm{Sv} / \mathrm{y}, 0.08 \mathrm{mSv} / \mathrm{y}, 0.105)$ respectively. The range of value of Annual gonadal dose equivalent $(A G D E)$ are $(0.059$ to 0.132 ) and the mean is $0.08 \mathrm{mSv} / \mathrm{y}$ this average values do not exceed the permissible recommended limits, indicating that the hazardous effects of these radiations are negligible. The average of excess lifetime cancer risk (ELCR) is $5.3 \times 10^{-5}$ According to this average value, the risk of cancer is negligible. The activity concentration of ${ }^{232} \mathrm{Th},{ }^{226} \mathrm{Ra}$ and ${ }^{40} \mathrm{~K}$ in soil samples in this study areas have been compared with those from similar investigation in Iraq and other neighbor countries. The summary of the results are given in Table 4.

Table 3. Radiological effects parameters in Al-Najaf soil samples.

\begin{tabular}{|c|c|c|c|c|c|c|c|c|c|c|c|}
\hline Area & $\begin{array}{c}\mathbf{R a}_{\mathrm{eq}} \\
(\mathbf{B q} / \mathbf{K g}) \\
\end{array}$ & $\mathbf{H}_{\mathrm{ex}}$ & $\mathbf{H}_{\mathrm{in}}$ & $\mathbf{I}_{\mathrm{Y}}$ & $\begin{array}{c}\text { D } \\
(\mathrm{nG} / \mathrm{h}) \\
\end{array}$ & AUI & $\begin{array}{c}\text { (RHP) } \\
\left(\mu \mathrm{W} / \mathbf{m}^{3}\right) \\
\end{array}$ & $\begin{array}{c}(\mathbf{A E D E})_{\text {Out }} \\
(\mathrm{mSv} / \mathrm{y})\end{array}$ & $\begin{array}{c}(\mathrm{AEDE})_{\mathrm{In}} \\
(\mathrm{mSv} / \mathrm{y})\end{array}$ & $\begin{array}{l}\text { AGDE } \\
\mathrm{mSv} / \mathrm{y}\end{array}$ & ELCR \\
\hline First kasser & 17.10 & 0.04 & 0.08 & 0.12 & 7.95 & 0.13 & 0.43 & 0.01 & 0.04 & 0.078 & $3.5 \times 10^{-5}$ \\
\hline Taktak & 25.48 & 0.09 & 0.10 & 0.13 & 11.99 & 0.17 & 1.09 & 0.01 & 0.04 & 0.083 & $3.5 \times 10^{-5}$ \\
\hline Al-sad & 21.49 & 0.06 & 0.08 & 0.16 & 10.28 & 0.13 & 1.28 & 0.013 & 0.05 & 0.072 & $4.5 \times 10^{-5}$ \\
\hline Al-rohanya & 37.70 & 0.10 & 0.15 & 0.275 & 17.8 & 0.24 & 1.79 & 0.022 & 0.09 & 0.124 & $7.7 \times 10^{-5}$ \\
\hline Abo-kamsat & 37.89 & 0.1 & 0.14 & 0.28 & 18.45 & 0.20 & 2.711 & 0.023 & 0.092 & 0.132 & $8 \times 10^{-5}$ \\
\hline Al-rehmauy & 28.23 & 0.06 & 0.11 & 0.20 & 13.37 & 0.19 & 1.24 & 0.016 & 0.065 & 0.093 & $5.6 \times 10^{-5}$ \\
\hline Al-maleh & 29.26 & 0.08 & 0.11 & 0.213 & 13.74 & 0.20 & 1.28 & 0.017 & 0.07 & 0.096 & $5.9 \times 10^{-5}$ \\
\hline $\begin{array}{c}\text { Second } \\
\text { kasser }\end{array}$ & 12.73 & 0.03 & 0.07 & 0.131 & 8.38 & 0.11 & 1.00 & 0.01 & 0.04 & 0.059 & $3.5 \times 10^{-5}$ \\
\hline Average & 26.23 & 0.07 & 0.1 & 0.188 & 11.02 & 0.17 & 1.35 & 0.015 & 0.061 & 0.08 & $5.3 \times 10^{-5}$ \\
\hline $\begin{array}{c}\text { Wared } \\
\text { average }\end{array}$ & $370^{*}$ & $<1^{*}$ & $<1^{*}$ & $<1^{*}$ & $55^{*}$ & & & $0.067^{* *}$ & $0.27^{* *}$ & $\begin{array}{c}0.363^{* *} \\
<0.3^{*}\end{array}$ & $0.29 \times 10^{-3 *}$ \\
\hline
\end{tabular}

\footnotetext{
*: reference $[25], * *$ : calculated
} 


\section{Al-Nahrain Journal of Science}

ANJS, Vol.24 (2), June, 2021, pp. 33-40

Table 4. Activity concentrations $(\mathrm{Bq} / \mathrm{kg})$ of ${ }^{232} \mathrm{Th},{ }^{226} \mathrm{Ra}$ and ${ }^{40} \mathrm{~K}$ measured in some Iraq's area as compared with neighbor countries.

\begin{tabular}{||c|c|c|c|c|c||}
\hline No. & Country & ${ }^{\mathbf{2 3 2}} \mathbf{T h}$ & ${ }^{\mathbf{2 2 6}} \mathbf{R a}$ & ${ }^{\mathbf{4 0}} \mathbf{K}$ & references \\
\hline \hline 1 & Jordan & 24.45 & 20.84 & 312.39 & {$[26]$} \\
\hline 2 & Egypt & 21 & 24 & 323.8 & {$[27]$} \\
\hline 3 & Iran & 14.9 & 26.3 & 271 & {$[28]$} \\
\hline 4 & Saudi Arabia & 20 & 23 & 233 & {$[29]$} \\
\hline 5 & Turkey & 50 & 22.2 & 247 & {$[30]$} \\
\hline 6 & Syria & 18.43 & 8.37 & 103.0 & {$[31]$} \\
\hline 7 & Kufa & 4.75 & 21.74 & 434.67 & {$[32]$} \\
\hline 8 & Baghdad & 25.81 & 33.55 & 326.74 & {$[33]$} \\
\hline 9 & Nineveh & 21.52 & & & {$[34]$} \\
\hline
\end{tabular}

\subsection{Multivariate statistical analysis}

The relationships were described among the radioactivity variables using the multivariate statistical analysis, such as basic statistical analysis, pearson correlation analysis and cluster analysis using SPSS (version17) software.

\section{a- Basic statistical analysis:}

The basic of statistical such as stander deviation, variance, skewness, kurtosis, mean, median, min., max. were used to describe the statistical characteristics of the radionuclide activities as shown in Table 5. The stander deviation of ${ }^{226} \mathrm{Ra},{ }^{232} \mathrm{Th}$ and ${ }^{40} \mathrm{~K}$ are less than the mean value this indicates that an irregular in their distribution. The skewness of activity concentrations of ${ }^{232} \mathrm{Th}$, and ${ }^{40} \mathrm{~K}$ are positive, that shows their distributions are symmetric towards positive values, while skewness of ${ }^{226} \mathrm{Ra}$ was negative that shows their distributions are asymmetric towards negative values. Generally, the skewness was low value so the form is normal distributions [35]. In this study, the kurtosis value of activity concentrations of ${ }^{226} \mathrm{Ra}$ and ${ }^{40} \mathrm{~K}$ are positive and the kurtosis value of ${ }^{226} \mathrm{Ra}$ is negative and it indicates that the curve is more peaked than the normal curve. Bell-shaped are shows in Figures 2,3 and 4 that shows the frequency distribution curve is normal and there are no radioactive hazards from all radionuclides ${ }^{232} \mathrm{Th},{ }^{226} \mathrm{Ra}$ and ${ }^{40} \mathrm{~K}$ in soil samples.

Table 5. Descriptive statistical of radioactive isotopes.

\begin{tabular}{||c|c|c|c||}
\hline Statistics & Th-232 & Ra-232 & K-40 \\
\hline \hline Mean & 4.9575 & 12.1025 & 101.3238 \\
\hline Median & 4.6350 & 12.6150 & 94.1150 \\
\hline Std. Deviation & 1.58658 & 3.50889 & 50.28744 \\
\hline Variance & 2.517 & 12.312 & 2528.827 \\
\hline Skewness & 0.359 & -0.611 & 1.127 \\
\hline Std. Error of Skewness & 0.752 & 0.752 & 0.752 \\
\hline Kurtosis & 0.416 & -0.668 & 2.453 \\
\hline Std. Error of Kurtosis & 1.481 & 1.481 & 1.481 \\
\hline Range & 5.20 & 10.09 & 172.60 \\
\hline Minimum & 2.51 & 6.34 & 31.52 \\
\hline Maximum & 7.71 & 16.43 & 204.12 \\
\hline \hline
\end{tabular}

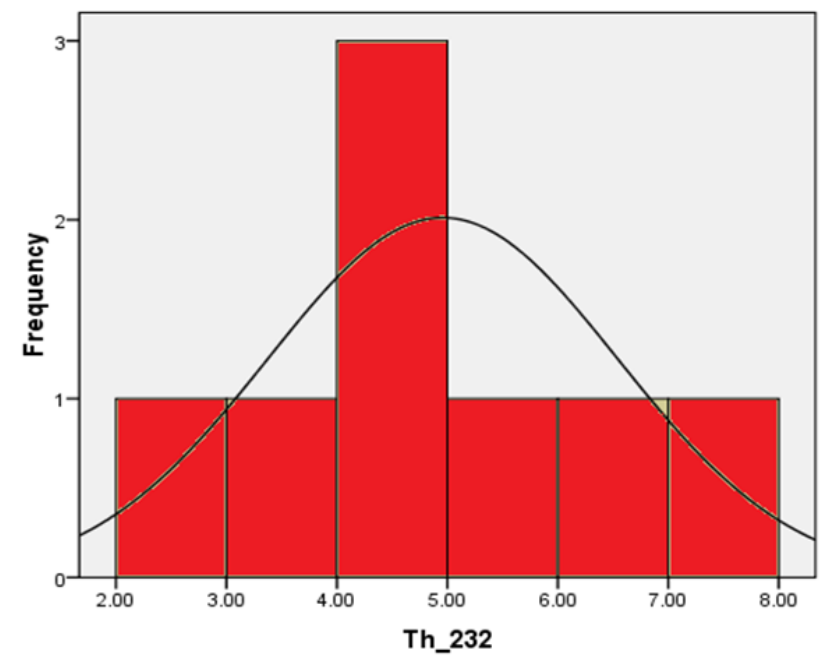

Figure 2. Frequency distribution of ${ }^{232} \mathrm{Th}$.

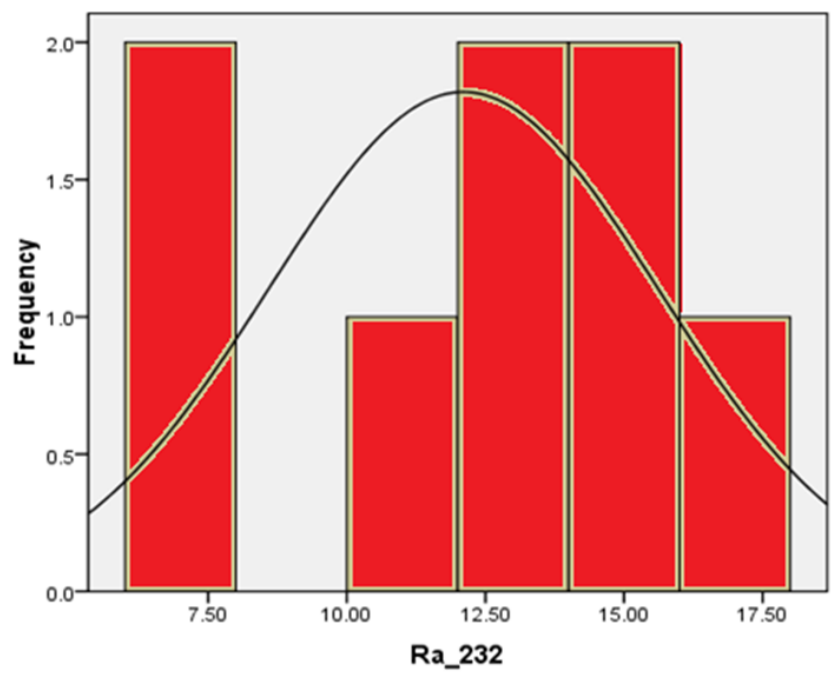

Figure 3. Frequency distribution of ${ }^{226} \mathrm{Ra}$. 


\section{Al-Nahrain Journal of Science}

ANJS, Vol.24 (2), June, 2021, pp. 33-40

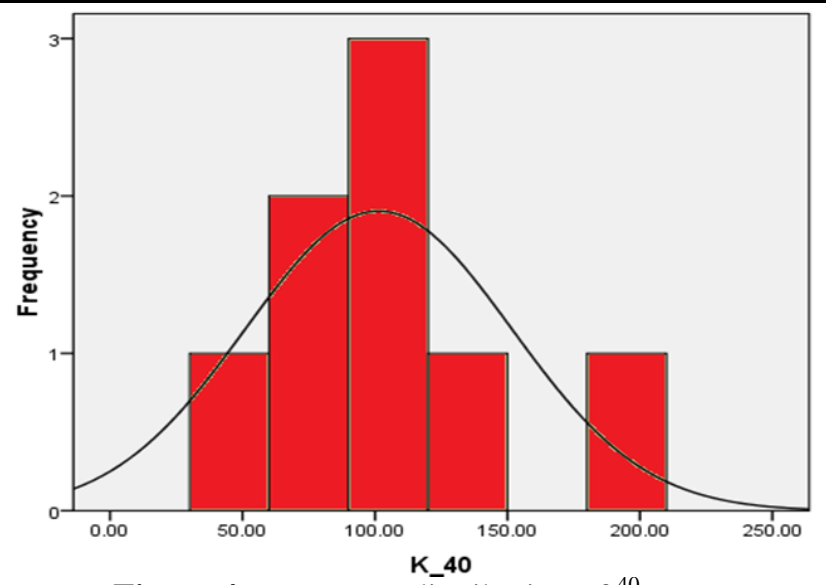

b- Pearson correlation analysis:

Pearson's correlation coefficient is the test statistics that measures the statistical relationship, or association, between two continuous variables. The correlation coefficient values of ${ }^{226} \mathrm{Ra}$ with ${ }^{232} \mathrm{Th}$ was seen a high degree- positive. The correlation coefficient values of ${ }^{226} \mathrm{Ra}$, ${ }^{232} \mathrm{Th}$ with ${ }^{40} \mathrm{~K}$ was seen a medium correlationpositive. Most of correlation coefficient values of ${ }^{226} \mathrm{Ra}$, ${ }^{232} \mathrm{Th}$ and ${ }^{40} \mathrm{~K}$ with radiological hazard parameters are high correlation and some of them are medium correlation and all the correlation coefficient values are positive [36] as shown in Table 6.

Figure 4. Frequency distribution of ${ }^{40} \mathrm{~K}$.

Table 6. Pearson correlation coefficients between the radioactive variables.

\begin{tabular}{|c|c|c|c|c|c|c|c|c|c|c|c|c|c|}
\hline & ${ }^{226} \mathbf{R a}$ & ${ }^{232} \mathrm{Th}$ & ${ }^{40} K$ & $\mathbf{R a}_{\mathrm{eq}}$ & Hex & Hin & Iy & D & AUI & RHP & $(\mathrm{AEDE})_{\text {Out }}$ & $(A E D E)_{\text {in }}$ & AGDE \\
\hline${ }^{238} \mathrm{u}$ & 1 & & & & & & & & & & & & \\
\hline${ }^{232} \mathrm{Th}$ & 0.596 & 1 & & & & & & & & & & & \\
\hline${ }^{40} \mathrm{~K}$ & 0.489 & 0.626 & 1 & & & & & & & & & & \\
\hline $\mathrm{Ra}_{\mathrm{eq}}$ & 0.875 & 0.799 & 0.808 & 1 & & & & & & & & & \\
\hline Hex & 0.744 & 0.808 & 0.732 & 0.919 & 1 & & & & & & & & \\
\hline Hin & 0.892 & 0.813 & 0.776 & 0.9754 & 0.873 & 1 & & & & & & & \\
\hline $\mathrm{Ir}$ & 0.74 & 0.79 & 0.866 & 0.9225 & 0.745 & 0.929 & 1 & & & & & & \\
\hline D & 0.817 & 0.823 & 0.878 & 0.9821 & 0.89 & 0.976 & 0.954 & 1 & & & & & \\
\hline AUI & 0.927 & 0.85 & 0.61 & 0.9418 & 0.852 & 0.953 & 0.854 & 0.914 & 1 & & & & \\
\hline RHP & 0.495 & 0.631 & 1 & 0.812 & 0.735 & 0.781 & 0.869 & 0.882 & 0.616 & 1 & & & \\
\hline$(\mathrm{AEDE})_{\mathrm{Out}}$ & 0.739 & 0.759 & 0.866 & 0.92 & 0.736 & 0.922 & 0.998 & 0.947 & 0.84 & 0.87 & 1 & & \\
\hline (AEDE)in & 0.758 & 0.773 & 0.848 & 0.9224 & 0.736 & 0.93 & 0.998 & 0.948 & 0.859 & 0.852 & 0.999 & 1 & \\
\hline AGDE & 0.861 & 0.706 & 0.819 & 0.9611 & 0.841 & 0.972 & 0.931 & 0.959 & 0.884 & 0.823 & 0.937 & 0.939 & 1 \\
\hline
\end{tabular}

\section{c- Cluster analysis:}

All parameters were grouped into two statistically clusters: cluster I consists of radioactivity of $\left({ }^{226} \mathrm{Ra}\right.$ and $\left.{ }^{232} \mathrm{Th}\right)$ and all-important radiological hazard and the cluster II consists of ${ }^{40} \mathrm{~K}$ radioactivity as shown in Figure 5. Result indicated that the concentration of ${ }^{226} \mathrm{Ra}$ and ${ }^{232} \mathrm{Th}$ are contributing from the radiation hazard more than ${ }^{40} \mathrm{~K}$. In general, there are not radiation hazard in the natural radioactivity from ${ }^{226} \mathrm{Ra}$ and ${ }^{232} \mathrm{Th}$ series and ${ }^{40} \mathrm{~K}$ in the soil samples at the study location.

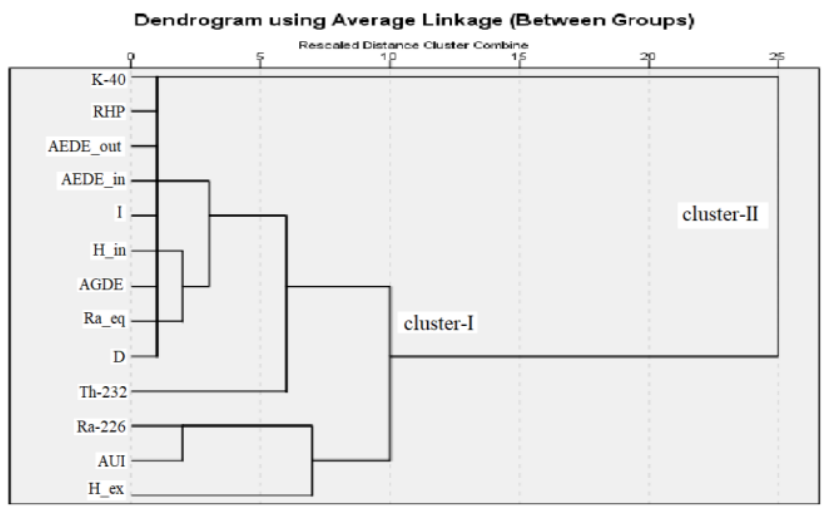

Figure 5 The clustering of variables.

\section{Conclusion}

The activities concentration of ${ }^{232} \mathrm{Th},{ }^{226} \mathrm{Ra}$ and ${ }^{40} \mathrm{~K}$ in soil samples in Najaf using $\mathrm{HpGe}$ gamma ray spectrometry were carried out. The results obtained in this study revealed that the distribution of natural radionuclides was relatively uniform. The activity concentrations levels appear lower than the neighbor countries average values. In this experimental work, the mean values of the obtained radiological effects were within the limited of the international recommended value. The study concluded the absence of harmful radiation effects that may be exposed to the population living in the study area. This study could be used as a database and this data might be useful for the natural radioactivity mapping.

\section{Acknowledgments}

The authors would like to acknowledge the support of the Iraqi Ministry of Science and Technology for completing this manuscript.

\section{References}

[1] Taqi A. H. and Al-Ani L. A. A.; "Assessment of Natural Radioactivity Levels in Kirkuk oil field"; J. Radiat. Res. Appl., 9(3), 337-344 2016. https://doi.org/10.1016/j.jrras.2016.02.007 


\section{Al-Nahrain Journal of Science}

ANJS, Vol.24 (2), June, 2021, pp. 33-40

[2] Rohit M.; Sandeep K.; Rajendra S. N. P. S. and Komal B.; "Analysis of terrestrial naturally occurring radionuclides in soil samples from some areas of Sirsa district of Haryana, India using gamma ray spectrometry"; J. Environ. Earth Sci., 59, 1159-1164, 2010. https://www.researchgate.net/publication/227146849

[3] Al-Aamer A.S.; "Assessment of human exposures to natural sources of radiation in soil of Riyadh, Saudi Arabia"; Turkish J. Eng. Environ. Sci., 32, 229-234, 2008.

https://www.researchgate.net/publication/228474664 Akhtar N.; Tufail M. and Ashraf M.; "Natural environmental radioactivity and estimation of radiation exposure from saline soils "; Int J Environ Sci Te, 1(4), 279-285, 2013.

https://link.springer.com/article/10.1007/BF03325843

[4] Ghazwa A.; Fauziah B. S. H. and Abdul Rahmanm I.; "Assessment of Natural radioactivity levels and radiation hazards in agricultural and virgin soil in the State of Kedah, North of Malaysia"; Sci. World J., 2016, 1-9, 2016. http://dx.doi.org/10.1155/2016/6178103

[5] Augustine K. A.; Adekunle K. B. and Adeniyi C. A.; "Determination of natural radioactivity and hazard in soil samples in around gold mining area in Itagunmodi, south-western, Nigeria"; J. Radiat. Res. Appl., 7, 249255, 2014. https://doi.org/10.1016/j.jrras.2014.06.001.

[6] Tadelech S. M. and Tilahun T. D.; "Investigations of natural radioactivity levels and assessment of radiological hazard of tea samples collected from local market in Ethiopia "; J. Nucl Part Phys, 10(1), 9-12, 2020. http://creativecommons.org/licenses/by/4.0/

[7] Usikalu M. R.; Maleka P. P.; Malik M.; Oyeyemi K. D. and Adewoyin O. O.; "Assessment of gelogenic natural radionuclide contents of soil samples collected from Ogun State, South western, Nigeria"; Int. J. Radiat. Res., 13(4), 355-361 2015. http://ijrr.com/article-1-1591-en.html

[8] Entesser F. S.; Mohsin K. M. and Jwad K. M.; "Radioactivity Natural environmental radiation in middle of Iraq governorates", Adv Tech Biol Med, 8(2) 272: 1-4, 2020.

[9] Şeref T.; "The natural radioactivity in drinking water by gross alpha and beta measurements and radiological quality assessment"; Radiochim. Acta, 108, 6, 2019, https://doi.org/10.1515/ract-2019-3175

[10] Ali B. M.; "Hydro geological Study of area between Najaf-Karbalaa cities, Iraqi"; J. Sci.; 53(2), 353-361 2012.

https://www.iasj.net/iasj?func=article\&aId=53009

[11] Veiga R.; Sanches N.; Anjos R. M.; Macario K.; Bastos J.; Iguatemya M.; Aguiar J. G.; Santos A. M. A.; Mosquera B.; Carvalho C.; et al. "Measurement of natural radioactivity in Brazilian beach sands"; J. Radiat. Meas.; 41, 189-196, 2006.

https://doi.org/10.1016/j.radmeas.2005.05.001
[12] Al-Hamidawi A. A.; Al-Gazaly H. H. and Al-Alasadi L. A.; "Determination of natural radiation contamination for some types of legumes available in the Iraqi markets"; J. Adv Appl Sci Res., 4(5), 245$250,2013$.

https://www.researchgate.net/publication/314081069

[13] Agbalagba E. O.; Avwiri G. O. and Chad-Umoreh Y. E.; "Gamma-Spectroscopy measurement of natural radioactivity and assessment of radiation hazard indices in soil samples from oil fields environment of Delta State, Nigeria"; J. Environ. Radioact., 109, 6470, 2012. doi:10.1016/j.jenvrad.2011.10.012

[14] Hmood A. N.; Alhesnawi A. Sh.; Hameed A. S. and Ashour N.; "Assessment of the natural radioactivity and concentrations of some heavy elements in the dust of some schools in Karbala, Iraq"; Iran. J. Medical Phys.; 16, 280-284, 2019.

https://www.researchgate.net/publication/334045795

[15] Harb S.; El-Kamel A. H.; Zahran E. M.; Abbady A. and Ahmed F. A.; "Natural radioactivity of soil samples from some areas of Aden governorate, south of Yemen region"; Int J Curr Microbiol Appl Sci, 3(11), 640-648, 2014. http://www.ijcmas.com

[16] Matiullah A.; Ur Rehman A.; Ur Rehman S. S. and Fahee M.; "Measurement of radioactivity in the Soil of Bahawalpur division, Pakistan"; Radiat Prot Dosimetry, 112(3), 443-447, 2004. https://doi.org/10.1093/rpd/nch409

[17] Tholkappian M.; Chandrasekaran A.; Ganesh D.; Chandramohan J.; Harikrishnan N. and Ravisankar R.; "Determination of Radioactivity levels and radiation hazards in coastal sediment samples of Chennai coast, Tamilnadu, India using gamma ray spectrometry with statistical Approach"; J. Radia, Nucl. Appli., 3(3), 171-182, 2018. http://dx.doi.org/10.18576/jrna/030307

[18] Sivakumara S.; Chandrasekaranb A.; Ravisankarc R.; Ravikumarc S. M.; Prince J.; Jebakumard P. P. J.; Vijayagopale P.; Vijayalakshmie I. and Josee M. T.; "Measurement of natural radioactivity and evaluation of radiation hazards in coastal sediments of east coast of tamilnadu using statistical approach"; J. Taibah Univ. Sci., 8(4), 375-384, 2014. https://doi.org/10.1016/j.jtusci.2014.03.004

[19] Abbady A. G. E. and Al-Ghamdi A. H.; "Heat production rate from radioactive elements of granite rocks in north and southeastern Arabian shield Kingdom of Saudi Arabia"; J. Radiat. Res. Appl. Sci., 11, 281-290, 2018. https://doi.org/10.1016/j.jrras.2018.03.002

[20] Sivakumar S.; Chandrasekaran A.; Senthilkumar G.; Gandhi M. S. and Ravisankar R.; "Determination of radioactivity levels and associated hazards of coastal sediment from south east coast of Tamil Nadu with statistical approach"; Iran J Sci Technol Trans., 48(2), 601-614, 2018.

http://dx.doi.org/10.1007/s40995-017-0184-2 


\section{Al-Nahrain Journal of Science}

ANJS, Vol.24 (2), June, 2021, pp. 33-40

[21] Mahmood S. K.; Hasan H. D. and Taghreed K. H.; "Measurement of natural radioactivity in selected soil samples from the archaeological of Babylon city, Iraq"; Journal of Radiation and Nuclear Applications, 1(1), 31-35, 2016. http://dx.doi.org/10.18576/jrna/010105

[22] Nimet Z. and Hakan A.; "Assessment of radioactivity levels and radiation hazards using gamma spectrometry in soil samples of Edirne, Turkey"; J. Radioanal. Nucl. Chem, 310(3), 959-967, 2016. https://www.researchgate.net/publication/305211826

[23] Senthilkumar R. D. and Narayanaswamy R.; "Assessment of radiological hazards in the industrial effluent disposed soil with statistical"; J. Radiat. Res. Appl., 9, 449-456, 2016. https://doi.org/10.1016/i.jrras.2016.07.002

[24] United National Scientific Committee on the Effects of Atomic Radiation, Source and effects and risks of ionizing radiation (2000). "Report to the general assembly with annexes", New York, United Nations.

[25] Salaheddin R. M.; El-Gohary M.; Mohammad O.; Danah A.; Al-Mistarihi Q. and Al-Malahim E.; "Investigation of radioactivity levels in soil at JUST campus prior to the construction of JRTR"; Jordan J. Civ. Eng., 7 (4), 371-476, 2013.

[26] Badawy, W. M.; El-Kameesy S. U.; Soliman N. F.; Eissa H. S. and Mahmoud A. W.; "Natural radioactivity and the associated dose from the terrestrial ecosystem of Ismailia Canal, Egypt"; Int. J Adv. Res, 3(1), 768-778, 2015. http://www.journalijar.com

[27] Faghihi R.; Mehdizadeh S. and Sina S.; "Natural and artificial radioactivity distribution in soil of Fars Province, Iran"; Oxford Radiat Prot Dosimetry, 145(1), 66-74, 2011. https://doi.org/10.1093/rpd/ncq36

[28] Al-Mugren K. S.; "Assessment of natural radioactivity levels and radiation dose rate in some soil samples from historical area, Al-Rakkah, Saudi Arabia"; J. Scirp, 7, 238-247, 2015. http://dx.doi.org/10.4236/ns.2015.75027

[29] Osman A.; Canel E.; Ismail B. and Emin M. K, "Determination of naturally occurring radionuclides in soil samples of Ayranc1, Turkey"; J. Phys. Conf. Ser., 590, 1-4, 2015. https://www.researchgate.net/publication/275240393

[30] Yassin T.; "Natural radioactivity in the Syrian environment"; J. Sci Total Environ, 170(1), 119-124, 1995. https://doi.org/10.1016/0048-9697(95)04610-D

[31] Raad O. H.; "Measurement of natural radioactivity in the Soil of Kufa city-Iraq", J. Kufa Phys., 6(2), 45-57, 2014.

[32] Adel M. S.; Al-Mashhadaniand A. H. and Murtdha A. S.; "Natural radioactivity concentration and estimation of radiation exposure in environmental soil samples from Al-Sader city/Iraq"; IJCET, 4(4), 2902-2906, 2014.
[33] Najam L. A. and Younis Sh. A.; "Assessment of natural radioactivity level in soil samples for selected regions in Nineveh Province (IRAQ) "; Int. J. Novel Res. Phys. Chem., 2(2), 1-9, 2015. https://www.researchgate.net/publication/280609957

[34] Elsaman R.; Omer M. A. A.; El-Montaser M. S. and El-Taher A.; "Natural radioactivity levels and radiological hazards in soil samples around Abu Karqas sugar factory"; J. Environ. Sci. Technol., 11, 28-38, 2018. https://www.researchgate.net/publication/324775178

[35] Ajithra A. K.; Venkatraman B.; Jose M. T.; Chandrasekar S. and Shanthi G.; "Assessment of natural radioactivity and associated radiation indices in soil samples from the high background radiation area, Kanyakumari district, Tamil Nadu, India"; J. Radiat Prot Environ., 40(1), 27-33, 2017. https://www.researchgate.net/publication/316444272 